\title{
Purification and Characterization of a Polyphosphate Kinase from Arthrobacter atrocyaneus
}

\author{
By SUSAN L. LEVINSON, L. H. JACOBS, TERRY A. KRULWICH \\ AND H.-C. LI \\ Department of Biochemistry, Mount Sinai School of \\ Medicine of the City University of New York, \\ New York, New York, 10029, U.S.A.
}

(Received I6 September 1974; revised II November 1974)

\begin{abstract}
SUMMARY
Polyphosphate kinase, an enzyme which incorporated the $\gamma$-phosphate of ATP into long-chain polyphosphate molecules, was purified more than 700 -fold from Arthrobacter atrocyaneus by ammonium sulphate fractionation, DEAEcellulose column chromatography and Sephadex G-200 gel filtration. The enzyme had a broad $\mathrm{pH}$ optimum at 6.0 to 7.0 and required $\mathrm{Mn}^{2+}$ or $\mathrm{Mg}^{2+}$, histone, and inorganic phosphate for activity. The $K_{m}$ for $\mathrm{Mn}$-ATP was $0.53 \mathrm{mM}$, and for inorganic phosphate was $\mathrm{I} \cdot 67 \mathrm{~mm}$.

Free ATP concentrations greater than $8 \mu \mathrm{M}$ inhibited the enzyme. Free $\mathrm{Mn}^{2+}$ or $\mathrm{Mg}^{2+}$ concentrations greater than $2 \mathrm{mM}$ or $6 \mathrm{mM}$, respectively, were also inhibitory. Activity was strongly inhibited by $4 \mathrm{~mm}-\mathrm{ADP}, \mathrm{I} \mathrm{mm}-\mathrm{PP}$ or $20 \mathrm{mM}-\mathrm{NaF}$. The effect of ADP might have resulted from reversing the equilibrium of the kinase reaction. The activation by phosphate ions might indicate a role for the enzyme in regulating intracellular phosphate levels or maintaining a phosphorus reserve. The level of enzymic activity in the bacteria responded to changes in inorganic phosphate concentration in the medium. Basic proteins, such as protamine, could substitute for histone as activator. Proteins such as casein or bovine serum albumin would also substitute for histone but only in the absence of inorganic phosphate. The presence of a protein might be necessary to form a complex with the product, thus preventing reversal of the reaction in vitro.

The reaction product was characterized, and found to be labile in hydroxylamine, base, and acid at $100{ }^{\circ} \mathrm{C}$. It behaved as a long-chain-polyphosphate molecule on chromatography in an Ebel's solvent. The enzymic activity was therefore not that of a protein kinase.
\end{abstract}

\section{INTRODUCTION}

Long-chain polyphosphate was detected in many species of micro-organisms and in some higher plants and animals (Harold, 1966). An enzyme responsible for the formation of this compound, polyphosphate kinase, was detected in yeast (Yoshida \& Yamataka, 1953), Escherichia coli (Kornberg, Kornberg \& Simms, 1956; Li \& Brown, 1973) and various other micro-organisms. We have achieved a greater than 700 -fold purification of a polyphosphate kinase from the bacterium Arthrobacter atrocyaneus. The enzyme from $A$. atrocyaneus, like that from $E$. coli ( $\mathrm{Li} \&$ Brown, 1973), required both histone and inorganic phosphate for activity.

Because of its dependence on histone, the activity was initially thought to be a protein kinase (Schechter, Li \& Krulwich, 1972). However, characterizations of the product as well as the enzyme have shown that the latter was a histone-dependent polyphosphate 
kinase, which incorporated the $\gamma$-phosphate of ATP into long-chain polyphosphate molecules.

\section{METHODS}

Organism and growth conditions. Arthrobacter atrocyaneus (ATCCI3752) was grown on minimal medium MS (Krulwich et al. 1967) supplemented with $0.05 \mathrm{M}$-sodium glutamate as carbon source. For isolation of the polyphosphate kinase, I6 1 of culture were grown to the late exponential phase, in carboys, from a $100 \mathrm{ml}$ inoculum, with vigorous aeration, at $30{ }^{\circ} \mathrm{C}$. Phosphate-free medium for physiological studies contained 25 mM-tris $\mathrm{pH} 7 \cdot 2$, $0.2 \%$ ammonium sulphate, $0.02 \% \mathrm{MgSO}_{4}$, plus trace salts (Krulwich et al. 1967).

Preparation of crude extracts. Bacteria were harvested by centrifuging, washed with Io $\mathrm{mM}$-tris $\mathrm{pH} \mathbf{7 \cdot 2}$, and then resuspended in this buffer. The organisms were disrupted by sonication using a Heat Systems-Ultrasonics Wi $85 \mathrm{D}$ sonifier for a total of $2 \mathrm{~min}$. The temperature was kept below $10{ }^{\circ} \mathrm{C}$. The extract thus produced was then treated with DNAase $(3 \mathrm{mg} / \mathrm{ml})$ and RNAase $(3 \mathrm{mg} / \mathrm{ml})$ for $\mathrm{I} \mathrm{h}$ at $5{ }^{\circ} \mathrm{C}$. The debris was removed by centrifuging for $10 \mathrm{~min}$ at $16000 \mathrm{~g}$. When the extract was to be used for physiological studies, DNAase and RNAase treatments were omitted, and extracts were dialysed against Io $\mathrm{mM}$-tris $\mathrm{pH} 7 \cdot 2$ for $15 \mathrm{~h}$ with one change after centrifuging.

Enzyme assays. The activity of the polyphosphate kinase was determined at $30{ }^{\circ} \mathrm{C}$ in a mixture containing (except where noted): 6 mM-potassium phosphate buffer $\mathrm{pH} 7 \cdot 0$; $2 \mathrm{mM}-\mathrm{MnCl}_{2}$; histone type II from calf thymus (I mg/ml); $0.4 \mathrm{~mm}\left[\gamma-{ }^{32} \mathrm{P}\right] \mathrm{ATP}$ ( 7 to $28 \mathrm{~d} . \mathrm{p} . \mathrm{m} . / \mathrm{pmol}$ ); and $8.8 \mu \mathrm{g}$ enzyme $/ \mathrm{ml}$, in a total volume of $0.1 \mathrm{ml}$. [ ${ }^{32} \mathrm{P}$ ]polyphosphate was determined by the paper chromatographic procedure of Li \& Felmly (I973), except that the paper strips were not dried before elution and the solvent used was cold $10 \%(\mathrm{w} / \mathrm{v})$ TCA. One unit of activity is equivalent to that amount of enzyme which catalyses the incorporation of one nmol $\left[\gamma-{ }^{32} \mathrm{P}\right] \mathrm{ATP}$ into product/min. Activity of RNA polymerase was determined by the method of Bonner et al. (1968). Protein was determined by the method of Lowry et al. (I95I).

Chemicals. ${ }^{32} \mathrm{P}$-inorganic phosphate and $\left[\gamma_{-}{ }^{32} \mathrm{P}\right] \mathrm{ATP}$ were purchased from New England Nuclear Corp. Histone type II, protamine, casein, and bovine serum albumin were purchased from Sigma. Sephadex G-200 was purchased from Pharmacia, and DEAEcellulose from Bio-Rad. All other chemicals were of the highest quality commercially available.

\section{RESULTS}

Purification of the enzyme. The crude extract, prepared as described in Methods, was fractionated using ammonium sulphate, which was added to $45 \%$ of saturation with stirring at $\mathrm{o}$ to $5{ }^{\circ} \mathrm{C}$. The precipitated protein was centrifuged, dissolved in $5 \mathrm{ml}$ of $10 \mathrm{~mm}-$ tris buffer $\mathrm{pH} 7.2$ containing I mM-EDTA, and was then dialysed overnight at $5{ }^{\circ} \mathrm{C}$ against 21 of the same buffer with one change. The ammonium sulphate fraction was then applied to a DEAE-cellulose column $(\mathrm{I} \times 25 \mathrm{~cm})$ equilibrated with $5 \mathrm{~mm}$-potassium phosphate buffer $\mathrm{pH} 7 \cdot 0$. The protein was eluted by $500 \mathrm{ml}$ of a linear gradient from $5 \mathrm{~mm}$ - to $500 \mathrm{~mm}$-potassium phosphate $\mathrm{pH} 7 \cdot 0$, containing I mM-EDTA, IO mM-dithiothreitol, and $10 \%$ (w/v) glycerol (Fig. I). The active fractions ( $10 \mathrm{ml}$ ), which were eluted at approximately $0.22 \mathrm{M}$-potassium phosphate, were pooled and concentrated by the addition of ammonium sulphate to $45 \%$ of saturation. The precipitate collected was dissolved in I ml of $5 \mathrm{~mm}$-potassium phosphate containing I mM-EDTA, I0 mM-dithiothreitol and $10 \%$ $(w / v)$ glycerol, and dialysed against $\mathrm{I} l$ of this buffer overnight. The preparation was 


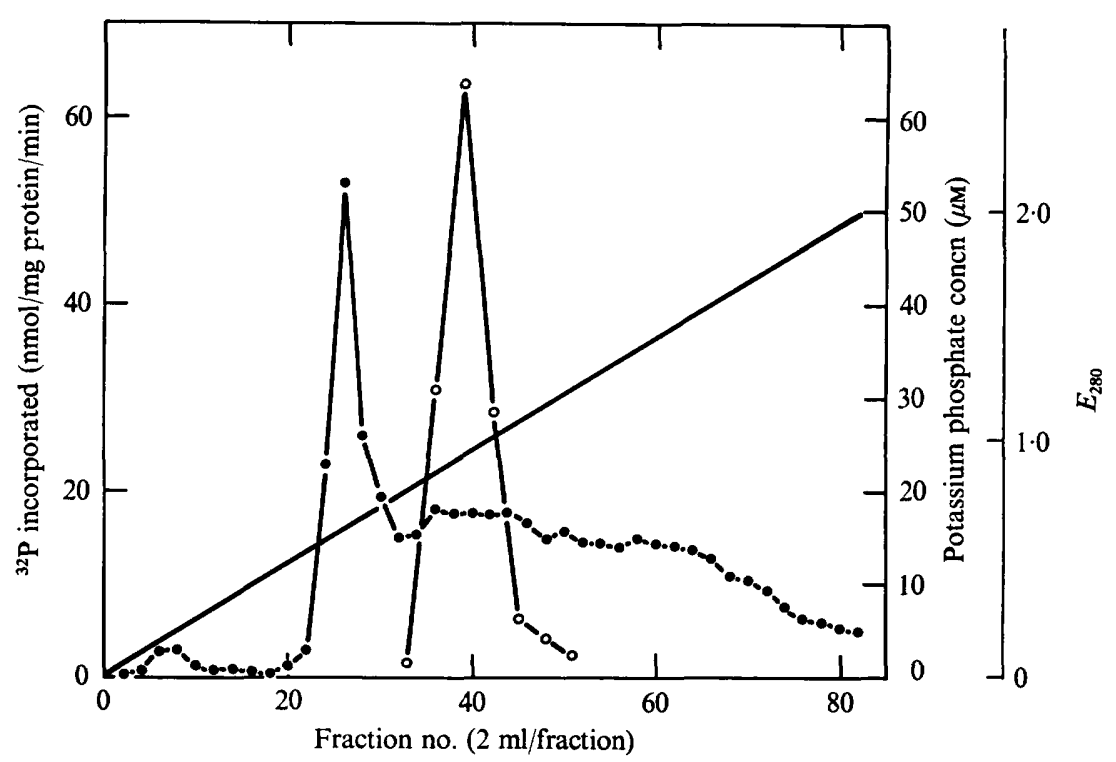

Fig. I. Elution of polyphosphate kinase from a DEAE-cellulose column. The enzyme fraction $(5 \mathrm{ml})$ obtained after ammonium sulphate precipitation was applied to a DEAE-cellulose column $(\mathrm{I} \times 24 \mathrm{~cm})$ equilibrated with $50 \mathrm{~mm}$-potassium phosphate $\mathrm{pH} 7.0$, and was eluted with a linear gradient from $5 \mathrm{~mm}$ - to $500 \mathrm{~mm}$-potassium phosphate $\mathrm{pH} 7 \cdot 0$, containing I mM-EDTA, $10 \mu \mathrm{M}-$ dithiothreitol, and $10 \%(\mathrm{w} / \mathrm{v})$ glycerol at $5{ }^{\circ} \mathrm{C}$. Fractions were assayed as described in Methods. $O$, Specific activity;,$E_{280} ;-$, potassium phosphate concentration.

\section{Table I. Purification of polyphosphate kinase}

The purification procedure is described in detail in Results. The preparations were assayed as described in Methods. Recoveries of enzyme are not quoted because of transient stimulations that were seen at some steps.

\begin{tabular}{|c|c|c|c|c|}
\hline Purification step & Units/ml & $\begin{array}{l}\text { Protein } \\
(\mathrm{mg} / \mathrm{ml})\end{array}$ & $\begin{array}{c}\text { Specific } \\
\text { activity } \\
\text { (nmol/mg/ } \\
\text { min) }\end{array}$ & $\begin{array}{l}\text { Purification } \\
\text { factor }\end{array}$ \\
\hline of crude extract & $6 \cdot 5$ & $5 \cdot 9$ & $I \cdot I$ & $\mathbf{I}$ \\
\hline honium sulphate precipitation & $77 \cdot 6$ & $6 \cdot 4$ & $\mathrm{I} 2 \cdot \mathrm{I}$ & I I \\
\hline ellulose chromatography & $33 \cdot 2$ & $0 \cdot 3$ & $99 \cdot 3$ & 89 \\
\hline um sulphate precipitation & $790 \cdot 6$ & $1 \cdot 7$ & $472 \cdot 0$ & 425 \\
\hline G-200 chromatography & $72 \cdot I$ & 0.09 & 818.8 & 738 \\
\hline
\end{tabular}

then applied to a Sephadex G-200 column $(2.5 \times 40 \mathrm{~cm})$ equilibrated with the same buffer used for dialysis. A sharp peak of activity was eluted approximately at the external void volume (data not shown). The purification procedure is summarized in Table I. The fractions eluted from the Sephadex G-200 column were used for all subsequent experiments. The enzyme preparation was stable at $5{ }^{\circ} \mathrm{C}$ for at least six months.

Characterization of the enzyme. The rate of formation of product remained linear for I 5 min (Fig. 2). The enzyme exhibited a broad $\mathrm{pH}$ optimum at 6.0 to 7.0 (Fig. 3). The enzyme preparation was free from RNA polymerase activity, although McConnell \& Bonner (1972) have reported that the two enzymes from $E$. coli may be purified together.

The polyphosphate kinase apparently required a metal ion-ATP complex as substrate rather than free ATP. Either $\mathrm{Mg}_{-} \mathrm{ATP}^{2-}$ or $\mathrm{Mn}-\mathrm{ATP}^{2-}$ was able to serve as substrate. 


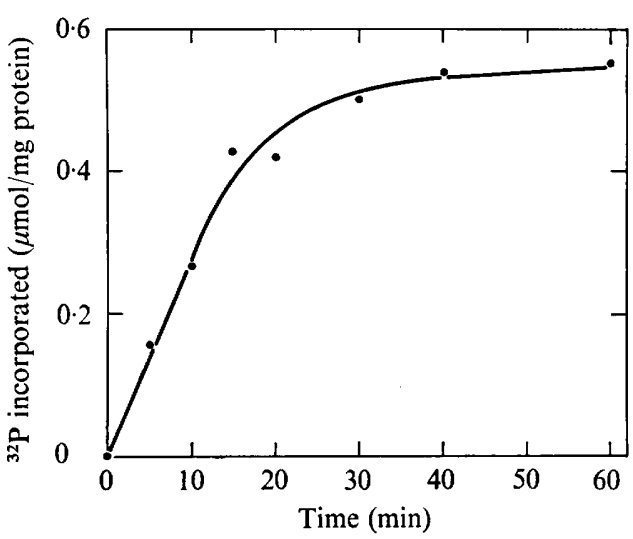

Fig. 2.

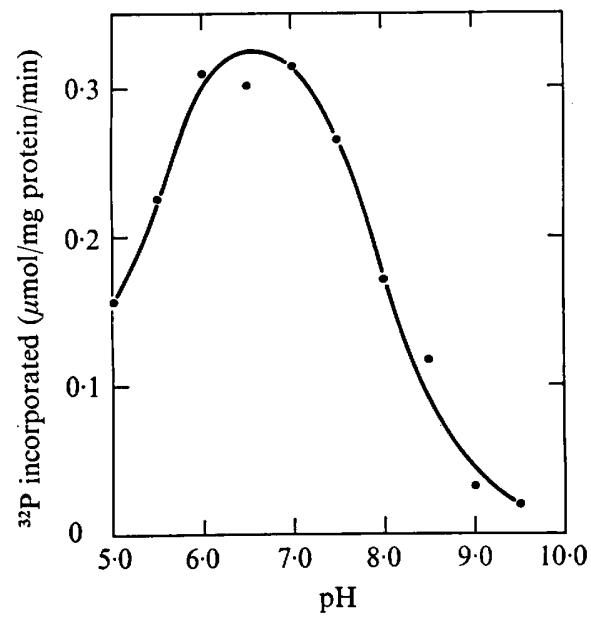

Fig. 3.

Fig. 2. Time course of the polyphosphate kinase reaction. The enzyme was assayed as described in Methods except that a final volume of $0.2 \mathrm{ml}$ was employed. Samples of reaction mixture were removed at appropriate times and radioactively labelled product was determined as described.

Fig. 3. Dependence of the polyphosphate kinase reaction on $\mathrm{pH}$. The assay was performed in a total volume of $\mathrm{O} . \mathrm{I} \mathrm{ml}$, containing histone type II (I mg/ml), $2 \mathrm{~mm}-\mathrm{MnCl}_{2}, 6 \mathrm{~mm}$-potassium phosphate $\mathrm{pH} 7 \cdot 0,20 \mu \mathrm{l}$ water, $0.4 \mathrm{~mm}-\left[{ }^{32} \mathrm{P}\right] \mathrm{ATP}$ and $50 \mathrm{~mm}$-tris-maleate-acetate buffer $\mathrm{pH} 5$ to $9 \cdot 6$. This mixture was incubated for $\mathrm{Io}$ min at $30^{\circ} \mathrm{C}$ and radioactively labelled product was determined as described in Methods.

Values could be calculated for the concentrations in our assay of the dissociated components of the complex, $\mathrm{Mn}^{2+}$ and ATP, by using the stability constant $56230 \mathrm{M}^{-1}$ for the Mn-ATP2- complex as determined by Walaas (1958). At high concentrations of Mn-ATP ${ }^{2-}$ complex, i.e. greater than $0.6 \mathrm{mM}$, the enzyme was inhibited (data not shown). It could be calculated that levels of free ATP (i.e. not in complex with $\mathrm{Mn}^{2+}$ ) of greater than $8 \mu \mathrm{M}$ caused inhibition of the enzyme.

When the levels of free $\mathrm{Mn}^{2+}$ were varied while the $\mathrm{Mn}-\mathrm{ATP}^{2-}$ complex was maintained at a constant level and the free ATP concentrations were maintained below inhibitory levels, it could be shown that free $\mathrm{Mn}^{2+}$ also inhibited enzymic activity (Fig. 4) at concentrations greater than $2 \mathrm{mM}$. Optimal activity was observed in the presence of $\mathrm{I} \cdot \mathrm{O}$ to 2.0 mM- $\mathrm{Mn}^{2+}$. At non-inhibitory concentrations of free ATP and $\mathrm{Mn}^{2+}$, a $K_{m}$ of $0.53 \mathrm{mM}$ was calculated for $\mathrm{Mn}^{-\mathrm{ATP}^{2-}}{ }^{2}$. Similar experiments with $\mathrm{Mg}^{-\mathrm{ATP}^{2-}}$ as substrate gave comparable results.

Phosphate ions were required for enzymic activity. Activity increased with increasing phosphate concentration up to approximately $5 \mathrm{~mm}$ (Fig. 5). A $K_{m}$ of I.67 mM was calculated. Radioactively labelled phosphate was not incorporated into the product.

The enzyme was strongly inhibited by ADP, one of the reaction products. When 4 mM-ADP was added at zero time or after Io min, the reaction was stopped (Fig. 6). Also shown in Fig. 6 are the inhibitory effects of $I \mathrm{mM}-\mathrm{PP}_{\mathrm{i}}$ or $20 \mathrm{mM}-\mathrm{NaF}$, which are similar to effects reported in E. coli (Kornberg et al. 1956; Li \& Brown, 1973).

The enzyme also required histone for activity (Fig. 7). Other proteins, such as protamine, could substitute for histone to a lesser degree. Bovine serum albumin and casein could also substitute for histone. However, in contrast to the activity observed with basic 


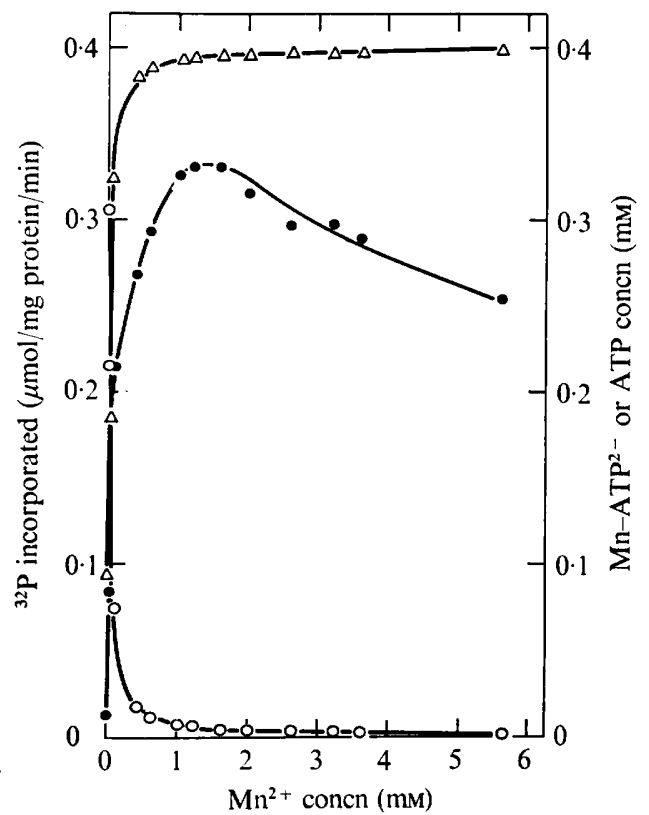

Fig. 4.

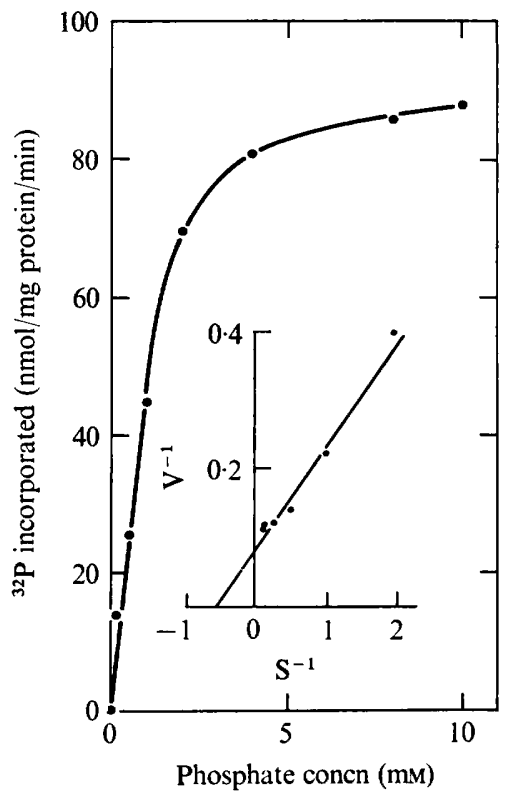

Fig. 5 .

Fig. 4. Dependence of the polyphosphate kinase reaction on the $\mathrm{MnCl}_{2}$ concentration. Assays were performed as described in Methods except that the concentration of $\mathrm{MnCl}_{2}$ was varied. Values for $\mathrm{Mn}^{2+}$, ATP, and $\mathrm{Mn}-\mathrm{ATP}^{2-}$ were determined from the dissociation constant for the

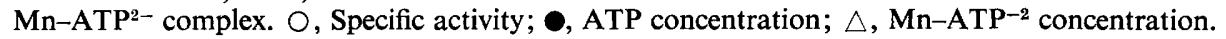

Fig. 5. Dependence of the polyphosphate kinase reaction on the presence of inorganic phosphate. Assays were performed as described in Methods except that the inorganic phosphate concentration was varied from o to Io mM. The reciprocal plot gave a $K_{m}$ of $\mathrm{I} .67 \mathrm{~mm}$.

proteins, enzymic activity in the presence of these two proteins could be detected only in the absence of inorganic phosphate (Table 2). The requirement for a protein, such as histone, might result in mistaken identification of the enzyme as a protein kinase. This possibility was eliminated for the enzyme from $A$. atrocyaneus by the characterization of the product.

Characterization of the reaction product. Determination of the chemical nature of the product was based on the known properties of the various phosphorylated protein residues and polyphosphate when treated by certain methods. It was initially thought that the reaction product might be either a phosphorylated protein, containing residues of acyl, serine, or imidazole phosphate, or a long-chain polyphosphate. Serine phosphate ester bonds are stable to hydroxylamine treatment, but labile in acid at $100{ }^{\circ} \mathrm{C}$ and in base (Kabat, I970; Agabian, Rosen \& Shapiro, 1972). Imidazole phosphate bonds are stable in base but labile in cold acid (Kundig \& Roseman, 1971). Acyl phosphate bonds are labile to treatment with $\mathrm{NH}_{2} \mathrm{OH}$, base or acid at $100{ }^{\circ} \mathrm{C}$ (Martonosi, I969; Hokin, Sastry, Galsworthy \& Yoda, 1965). Long-chain polyphosphate, having anhydride bonds like the acyl phosphate, would be broken down to inorganic phosphate in acid at $100{ }^{\circ} \mathrm{C}$, in base at $40^{\circ} \mathrm{C}$, and in hydroxylamine.

To obtain the product for characterization, the reaction was conducted for $\mathrm{I} h$ and stopped by the addition of a solution of TCA to give a final concentration of $10 \%(\mathrm{w} / \mathrm{v})$. The precipitate was centrifuged, resuspended in $\mathrm{I}$ ml of $5 \mathrm{~mm}$-potassium phosphate $\mathrm{pH} 7 \cdot 0$, 


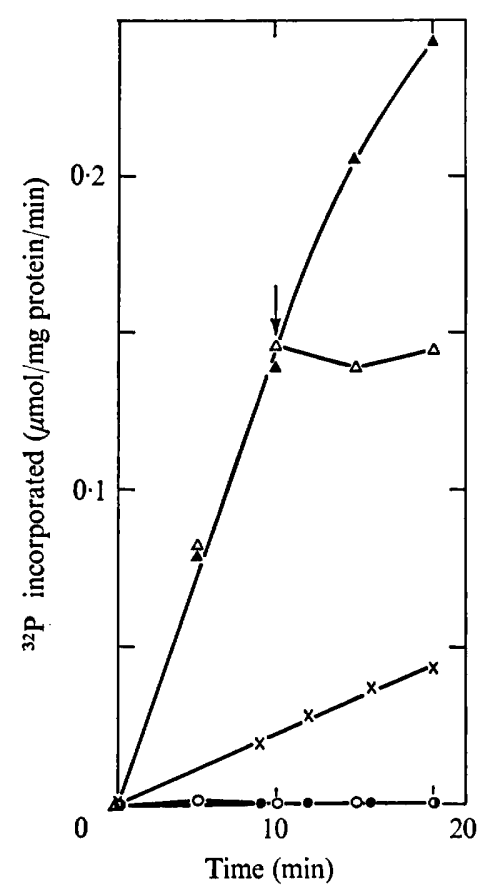

Fig. 6.

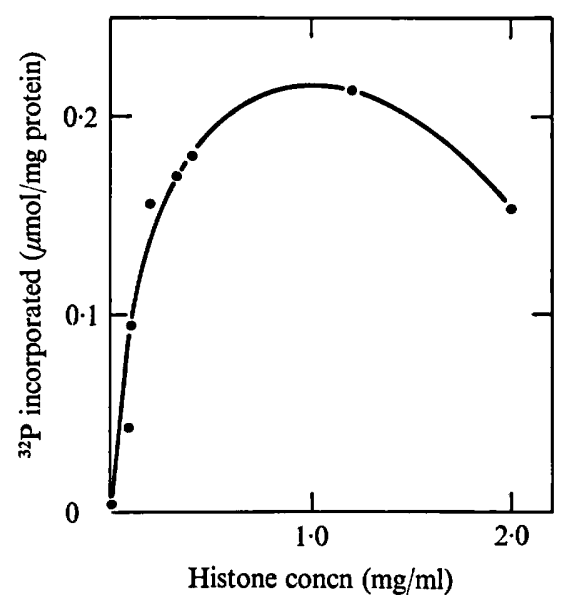

Fig. 7 .

Fig. 6. Inhibition of the polyphosphate kinase reaction by ADP, NaF, and pyrophosphate. Assays were performed as described in Methods in a volume of $0.2 \mathrm{ml}$, with the following added to each of three tubes at time zero: $0,4 \mathrm{mM}-\mathrm{ADP} ; \times, 20 \mathrm{mM}-\mathrm{NaF} ; 0$, I mu-pyrophosphate. $\triangle$, ADP $(4 \mathrm{~mm})$ was added to one tube after ro min (arrow). The control $(\boldsymbol{\Delta})$ contained no additions.

Fig. 7. Dependence of the polyphosphate kinase reaction on the histone concentration. Assays were performed as described in Methods except that the histone concentration was varied from 0 to $2 \cdot 0 \mathrm{mg} / \mathrm{ml}$.

and washed twice with $10 \%(\mathrm{w} / \mathrm{v})$ TCA. It was then resuspended in I $\mathrm{ml}$ of the same buffer, neutralized, and dialysed overnight at $5{ }^{\circ} \mathrm{C}$ against a large volume of 5 mm-potassium phosphate $\mathrm{pH} 7 \cdot 0$. The product was then subjected to the following conditions: (i) $\mathrm{I} \cdot 2 \mathrm{M}-$ $\mathrm{HCl}$ for $15 \mathrm{~min}$ at $100^{\circ} \mathrm{C}$; (ii) $0.5 \mathrm{M}-\mathrm{KOH}$ for $2 \mathrm{~h}$ at $40^{\circ} \mathrm{C}$; (iii) I M-hydroxylamine for $30 \mathrm{~min}$ at room temperature; (iv) papain $(2.5 \mathrm{mg} / \mathrm{ml})$ for $30 \mathrm{~min}$ at $37^{\circ} \mathrm{C}$. After treatment, each sample was spotted on strips of Whatman No. I filter paper. The strips were eluted for $16 \mathrm{~h}$ with an Ebel's solvent containing $735 \mathrm{ml}$ isopropanol, $50 \mathrm{~g}$ TCA, 2.5 $\mathrm{ml}$ conc. $\mathrm{NH}_{4} \mathrm{OH}$ (sp.gr. 0.88) and $265 \mathrm{ml}$ water; $100 \mathrm{ml}$ of the solvent was diluted with $25 \mathrm{ml}$ water before using (Ohashi \& Van Wazer, I963). On elution, long-chain polyphosphate remained at the origin while inorganic phosphate migrated rapidly. Shorter polyphosphate molecules migrated from the origin with intermediate $R_{F}$ values depending on chain length. After elution the strips were air-dried and counted in a Baird Atomic strip counter, which was adjusted to give maximum sensitivity while keeping background radioactivity low.

Radioactive ATP and inorganic phosphate standards were applied to the paper as were the samples, and eluted similarly. They migrated rapidly on the paper and separated well from each other (data not shown). Untreated radioactive product remained at the origin after chromatography. The chromatogram contained no residual radioactive ATP 
Table 2. Effect of inorganic phosphate on polyphosphate kinase reaction with different proteins

\begin{tabular}{|c|c|c|}
\hline Protein ( $\mathrm{I} \mathrm{mg} / \mathrm{ml}$ ) & $\begin{array}{l}\text { Inorganic phosphate } \\
(6 \mathrm{mM}) \text { added }\end{array}$ & $\begin{array}{l}\text { Specific activity } \\
\text { (nmol } / \mathrm{mg} / \mathrm{min} \text { ) }\end{array}$ \\
\hline Histone & + & $\begin{array}{r}254 \cdot 1 \\
19 \cdot 9\end{array}$ \\
\hline Protamine & $\begin{array}{l}+ \\
-\end{array}$ & $\begin{array}{r}135.0 \\
0.6\end{array}$ \\
\hline Casein & + & $\begin{array}{l}0.5 \\
4 \cdot 1\end{array}$ \\
\hline Bovine serum albumin & + & 6.6 \\
\hline & - & $59 \cdot 0$ \\
\hline
\end{tabular}

from the reaction, which indicated that washing twice with TCA was sufficient to remove unreacted substrate. After chromatography of the sample treated with acid, no counts remained at the origin; the product was completely hydrolysed to inorganic phosphate. After $\mathrm{KOH}$ treatment and elution with solvent, $19 \%$ of the counts remained at the origin. This suggested that the product was not protein containing imidazole phosphate bonds, which are stable to base under the conditions employed. Hydroxylamine caused the release of all but $8 \%$ of the counts from the origin. A serine phosphate ester product would be unaffected by this treatment. Seventy-two per cent of the product was unaffected by papain treatment. The loss of about $30 \%$ of the product after papain treatment might be due to some degradation of the histone needed to stabilize the product. However, a phosphorylated protein would show greater degradation after proteolytic treatment. This distinguished the reaction product from an acyl phosphorylated protein which resembled polyphosphate on the basis of the other criteria tested. The labile nature of the product was in accord with results found by other investigators (Kornberg et al. 1956; Li \& Brown, 1973; Mühlradt, 197I) and was compatible with the identification of the reaction product as polyphosphate rather than a phosphorylated protein.

Physiological studies. Phosphorus storage may be the physiological role of the polyphosphate kinase. Activity of the enzyme was determined under different conditions in dialysed crude extracts of the bacteria. Extracts which were frozen and thawed once before assaying sometimes showed an increase of from three- to fivefold over the activity of the same extract before freezing. One possible explanation of this observation was that the enzyme might be loosely associated with the bacterial membrane. Freezing and thawing might have caused its release when sonication had not already done so.

To examine the effects of inorganic phosphate in the medium on polyphosphate kinase activity, A. atrocyaneus was grown on the phosphate-free medium described in Methods with $50 \mathrm{~mm}$-malate as carbon source. Potassium phosphate was added to three separate cultures at 5, 25 and $100 \mathrm{~mm}$ concentrations. Dialysed crude extracts were frozen and thawed before assaying. The specific activities for organisms grown in the presence of 5,25 and $\mathrm{I00} \mathrm{mM}$ inorganic phosphate were $2 \cdot 6, \mathrm{I} \cdot 4$, and $0 \cdot 3 \mathrm{nmol}$ of ${ }^{32} \mathrm{P}$ incorporated into product $/ \mathrm{min} / \mathrm{mg}$ protein, respectively. The results indicated a direct relationship between the availability of phosphate in the medium and the activity of the polyphosphate kinase. 
To demonstrate derepression of this enzyme, organisms were grown on medium MS plus $50 \mathrm{~mm}$-malate overnight. These bacteria were harvested, washed, resuspended in 21 of phosphate-free medium and returned to the shaker at $30^{\circ} \mathrm{C}$. At $0,10,20$ and $30 \mathrm{~min}$, samples $(250 \mathrm{ml})$ were removed and crude extracts were prepared, dialysed, frozen and thawed for assay. The specific activities of the extracts were $0 \cdot 08,3.52,3.88$ and $4.78 \mathrm{nmol} /$ $\mathrm{min} / \mathrm{mg}$ protein, respectively. Thus, an extremely rapid increase in activity took place when organisms were aerated in the absence of inorganic phosphate. It is not clear whether the increase in activity was due to synthesis of new protein or to activation of inhibited enzyme already present.

\section{DISCUSSION}

Studies of enzyme induction in A. atrocyaneus led to the purification and characterization of a histone-dependent polyphosphate kinase. The requirement for histone to detect enzyme activity might be misleading. Unless the reaction product is purified, it might appear that the enzyme catalysed the phosphorylation of histone. When investigating protein kinase activity, one must therefore first eliminate the possibility of the presence of a histone-dependent polyphosphate kinase. The additional finding that inorganic phosphate inhibited or activated the enzyme when different proteins were used might also be used as a criterion for polyphosphate kinase activity where it is suspected. This characteristic has also been found for the E. coli enzyme (H.-C. Li \& G. G. Brown, personal communication). A possible role of histone or other proteins in the reaction might be to complex with the polyphosphate and prevent reversal of the reaction, thereby facilitating detection of the product. Depending on the protein, phosphate ions might interfere with this function or enhance it. Alternatively, the histone might interact with the enzyme, altering its activity in the presence of inorganic phosphate.

It is possible that ADP inhibited because it caused the equilibrium of the reaction to favour the reversal of polyphosphate synthesis. The results in Fig. 6 appear to contradict this, since radioactivity was not lost from the product on addition of ADP after Io min. However, if the role of histone were to complex with the product and prevent reversal of the reaction, it might mask the effect of ADP inhibition on product which was already formed. The reversal of the polyphosphate kinase reaction by ADP was shown in E. coli by Kornberg (1957) and Li \& Brown (1973).

The activation by inorganic phosphate might be consistent with a role for the enzyme, which has been suggested by others, for the accumulation of a phosphorus reserve. In many organisms, polyphosphate can be utilized as a phosphorus source for nucleic acid and phospholipid biosynthesis during spore germination (Nishi, I96I) or when organisms are starved for phosphorus (Harold, I966; Baker \& Schmidt, I964; Miyachi et al. 1964; Mudd, Yoshida \& Koike, I958; Winder \& Denneny, 1957). Sufficient amounts of polyphosphate might accumulate to allow the bacterial mass to double several times under conditions of phosphate starvation. The pattern of polyphosphate synthesis was studied in Aerobacter aerogenes by Harold (1966) with wild-type organisms and mutants of this bacterium deficient in polyphosphate metabolism. He found that under conditions of nucleic acid synthesis, polyphosphate synthesis was inhibited, possibly by competition for ATP, and degradation of polyphosphate was enhanced. When nutrient limitation stopped nucleic acid synthesis, inhibition of polyphosphate synthesis was relieved and polyphosphate degradation was inhibited. Kaltwasser (I962) suggested that accumulation of polyphosphate regulated the intracellular levels of inorganic phosphate. Conditions under which polyphosphate was synthesized were those where macromolecular synthesis was inhibited by 
nutrient starvation or specific inhibitors while uptake of inorganic phosphate from the medium continued. If the physiological role of polyphosphate were to serve as a phosphorus reserve, then it would be advantageous to the organism to have a polyphosphate-synthesizing enzyme which was sensitive to the levels of inorganic phosphate available.

Experiments designed to investigate the physiological role of the polyphosphate kinase strongly implicated involvement in phosphate metabolism of the bacteria. The levels of inorganic phosphate in the medium clearly correlated with levels of polyphosphate kinase, and derepression of the enzyme occurred when inorganic phosphate was removed from the medium. The role of the enzyme, therefore, might be to store phosphate internally at the expense of ATP when phosphate was available only in limiting amounts in the environment.

This work was supported by research grants AMi4663 from the National Institutes of Health and GB2048I from the National Science Foundation (to T.A.K.) and by a research grant GM 1927 I from the National Institutes of Health (to H.C.L.).

\section{REFERENCES}

Agabian, N., Rosen, O. M. \& Shapiro, L. (1972). Characterization of a protein acyl kinase from Caulobacter crescentus. Biochemical and Biophysical Research Communications 49, 1690-1698.

BAKER, A. L. \& SCHMIDT, R. R. (1964). Induced utilization of polyphosphate during nuclear division in synchronously growing Chlorella. Biochimica et biophysica acta 93, I80-182.

Bonner, J., Chalkley, G. R., Dahmus, M., Fambrough, D., Fujimura, F., Huang, R. C., Huberman, J., Jensen, R., Marushige, K., Ohlenbusch, H., Olivera, B. \& Widholm, J. (I968). Isolation and characterization of chromosomal nucleoproteins. Methods in Enzymology, vol. I2B. New York: Academic Press.

HAROLD, F. M. (I966). Inorganic polyphosphates in biology: structure, metabolism, and function. Bacteriological Reviews 30, 772-794.

Hokin, L. E., Sastry, P. S., Galsworthy, P. R. \& Yoda, A. (1965). Evidence that a phosphorylated intermediate in a brain transport adenosine triphosphatase is an acyl phosphate. Proceedings of the National Academy of Sciences of the United States of America 54, 177-184.

KABAT, D. (1970). Phosphorylation of ribosomal proteins in rabbit reticulocytes. Characterization and regulatory aspects. Biochemistry $9,4 \mathrm{I} 60-4 \mathrm{I} 75$.

Kaltwasser, H. (1962). Die Rolle der Polyphosphate im Phosphatstoffwechsel eines Knallgasbakteriums (Hydrogenomonas Stamm o). Archiv für Mikrobiologie 4I, 282-306.

KorNBERG, S. R. (1957). Adenosine triphosphate synthesis from polyphosphate by an enzyme from Escherichia coli. Biochimica et biophysica acta 26, 294-300.

Kornberg, A., Kornberg, S. R. \& Simms, E. S. (1956). Metaphosphate synthesis by an enzyme from Escherichia coli. Biochimica et biophysica acta 26, 21 5-227.

Krulwich, T. A., Ensign, J. C., TipPer, D. J. \& Strominger, J. L. (1967). Sphere-rod morphogenesis in Arthrobacter crystallopoietes. II. Peptides of the cell wall peptidoglycan. Journal of Bacteriology 94, $741-750$.

KundiG, W. \& Roseman, S. (1971). Sugar transport. I. Isolation of a phosphotransferase system from Escherichia coli. Journal of Biological Chemistry 246, 1393-1406.

LI, H.-C. \& BRowN, G. G. (I973). Orthophosphate and histone dependent polyphosphate kinase from E. coli. Biochemical and Biophysical Research Communications 53, 875-881.

LI, H.-C. \& Felmly, D. A. (I973). A rapid paper chromatographic assay for protein kinase. Analytical Biochemistry 52, 300-304.

Lowry, O. H., Rosebrough, N. J., Farr, A. L. \& Randall, R. J. (I95I). Protein measurement with the Folin phenol reagent. Journal of Biological Chemistry 193, 265-275.

Martonosi, A. (1969). Sarcoplasmic reticulum. VII. Properties of a phosphoprotein intermediate implicated in calcium transport. Journal of Biological Chemistry 244, 61 3-620.

McConnell, D. J. \& Bonner, J. (1972). Preparation of highly purified ribonucleic acid polymerase; separation from polynucleotide phosphorylase and polyphosphate kinase. Biochemistry II, 43294336. 
Miyachi, S., KanaI, R., Mihara, S., MiYaChi, S. \& Aoki, S. (1964). Metabolic roles of inorganic polyphosphates in Chlorella cells. Biochimica et biophysica acta 93, 625-634.

MudD, S., YoshidA, A. \& KoIKE, M. (1958). Polyphosphate as accumulator of phosphorus and energy. Journal of Bacteriology 75, 224-235.

MüHLRADT, P. F. (I97I). Synthesis of high molecular weight polyphosphate with a partially purified enzyme from Salmonella. Journal of General Microbiology 68, I I 5-I 22.

NishI, A. (196I). Role of polyphosphate and phospholipid in germinating spores of Aspergillus niger. Journal of Bacteriology 81, 10-19.

OHASHI, S. \& VAN WAZER, J. R. (1963). Paper chromatography of very long chain polyphosphates. Analytical Chemistry 35, 1984-1985.

SChechTeR, S. L., LI, H.-C. \& Krulwich, T. A. (1972). Regulation of inducible enzyme synthesis in Arthrobacter atrocyaneus. Abstracts of the Annual Meetings of the American Society for Microbiology, p. 176.

WALAAS, E. (1958). Stability constants of metal complexes with mononucleotides. Acta chemica scandinavica 12, 528-536.

Winder, F. G. \& DENNENY, J. M. (1957). The metabolism of inorganic polyphosphate in mycobacteria. Journal of General Microbiology $\mathbf{1 7}, 573-585$.

Yoshida, A. \& Yamataka, A. (1953). On the metaphosphate of the yeast. Journal of Biochemistry 40 85-94. 